\title{
The effect of organic mulch on the growth and yield of Spinach (Spinacia oleracea L) Absalom M Manyatsi ${ }^{1 *}$, Gcina R. Simelane ${ }^{2}$ \\ ${ }^{1}$ University of Swaziland, Department of Agricultural and Biosystems Engineering, M2005, Swaziland
}

\begin{abstract}
An experiment was conducted in a greenhouse at the Luyengo campus of the University of Swaziland to determine the effect of organic mulch on the growth and yield of spinach. The experiment was conducted between the months of January and February, 2017. The experiment was a completely randomized design (CRD), with treated sewage mulch (TSM) and organic compost mulch (OCM) as treatments. The no mulch (NML) was used as a control. Spinach seedlings were planted at a spacing of $15 \mathrm{~cm}$ within rows and $30 \mathrm{~cm}$ between rows. Weeding and pest control measures were done uniformly across the treatments, when and as required. The data collected included the percentage moisture retained by the different treatments on the soil, growth parameters (leaf width, leaf length, leaf number, leaf area, plant height) and yield at harvest. The results displayed a significant difference $(P<0.05)$ between the treatments in terms of the moisture retention properties. Organic compost mulch recorded the highest mean percentage moisture retention (22.9\%), followed by treated sewage mulch (20.9\%) and no mulch recorded the lowest percentage moisture retention in the soil (14.4\%). All the growth parameters were higher for spinach growth under TSM, followed by that grown under OCM. They were lowest under spinach grown under no mulch. The differences in mean for parameters were significant $(p<0.05)$. The yield also varied across the treatments as TSM had a dry mass of $43.0 \mathrm{~g}$, followed by OCM at $23.4 \mathrm{~g}$ and the no mulch treatment recorded a dry mass of $20.9 \mathrm{~g}$. The results showed that mulching improved the performance of the spinach plants in terms of plant growth, moisture retention and yield.
\end{abstract}

Keywords - Compost, mulch, organic, sewage, spinach.

\section{INTRODUCTION}

Spinach is one of the significant vegetables grown in the Kingdom of Swaziland. This green leafy vegetable is principally believed to have come from south-western Asia [1]. Production of spinach in the country is dominant on communal land where subsistence farming is practiced [2]. Subsistence agriculture is characterized by small scale production on a few square metres of land, mainly for the purpose of providing food for the families [3]. Spinach production is also important due to its health benefits as it supplies the body with nutrients such as Vitamin A, C and K. Vegetables such as spinach are also beneficial because they form a significant constituent of the Swazi nation's diet, because it can be served in a variety of dishes [4]. Low soil fertility intensity is one of the major contributors to the little productivity of vegetable crops in Swaziland. The fertility of the soil can be improved by the application of organic as well as inorganic fertilisers. The use of inorganic fertilisers proves to be very expensive and may also cause other side effects in the soil such as soil salinity [5].The use of organic methods such as composting, to restore soil fertility and soil physical properties has gained attention in the agricultural sector [6].

Compost has a similar composition to the soil organic matter thus it also enhances the physical properties of the soil such as the soil structure as well as the soils moisture and nutrient retention abilities [7]. Compost also helps maintain the nutrients in the soil for elongated periods of time since it is composed of differently sized constituents, which break down in the soil at varying decomposition rates, making the nutrients to be constantly available [8].Treated sewage sludge can also be used as a compost [9]. Sewage sludge contains vital plant nutrients as well as organic matter which may be utilized in crop production such as spinach, to substitute as well as increment the use of synthetic fertiliser in the country [10]. It enhances the physical, chemical and biological properties of the soil [11]. Plant nutrients contained in sewage sludge play an important role in the improvement of plant biomass [12]. The objective of the study was to determine the effect of compost on the growth and yield of spinach. 


\section{MATERIAL AND METHOD}

The experiment was carried out in a greenhouse at the University of Swaziland, Luyengo campus, which is located in the semi-arid region of the country. The greenhouse was located at $26.67543{ }^{\circ} \mathrm{S}$ latitude, $31.17867^{\circ} \mathrm{E}$ longitude at altitude of 735 $\mathrm{m}$ above sea level. This area is characterized by moderate temperatures and average annual rainfall.

The research was an experiment with Completely Randomized Design (CRD). The treatments for the experiment were organic compost mulch (OCM), treated sewage sludge mulch (TSM) and no mulch (NML) which was the control treatment. The organic compost mulch was acquired from a commercial supplier, while the treated sewage sludge was obtained from the sewage treatment plant for Manzini city located at longitude $31.23{ }^{\circ} \mathrm{E}$ and latitude $26.3567{ }^{\circ} \mathrm{S}$. Each treatment was replicated three times. The OCM and TSM treatments were applied at 400 grams per planting basin, at the time of transplanting. The experiment was conducted in well prepared plots and each plot had four spinach plants. The experiment had a total of 36 plants.

The planting plots were prepared to a fine tilth in the greenhouse using a fork and rake. The seedlings were obtained from a commercial supplier and they were planted at a spacing of $15 \mathrm{~cm}$ within rows and $30 \mathrm{~cm}$ between the rows. Weeding and pest control practices were carried out when and as required, according to weed growth or appearance of pests. The plants were watered after every two days using a watering can and each plant received 1litre of water based on the crop water consumptive use and the field capacity of the soil which was estimated using the oven drying method.

The data collected were moisture retention, leaf width, leaf length, leaf number, plant height, wet mass and dry mass. Three spinach plants were randomly selected from each plot for data collection. Growth parameters were measured on a weekly basis. The leaf width was measured by placing a ruler across the leaf in the middle part of the leaf. The plant leaf height was measured by using a measuring tape from the ground to the topmost part of the plant. The number of leaves was obtained by counting the individual leaves and the average number of leaves per treatment was used for data analysis. The leaf area was computed using equation 1 .

$$
\mathrm{LA}=(\mathrm{L} \times \mathrm{W} \times 0.7)
$$

Where;

$$
\begin{aligned}
& \text { LA - Leaf Area }\left(\mathrm{cm}^{2}\right) \\
& \text { L - Length of Leaf }(\mathrm{cm}) \\
& \text { W - Width of Leaf }(\mathrm{cm}) \\
& 0.7 \text { - Correction factor }
\end{aligned}
$$

The soil moisture retention properties of the different treatments were determined using the oven drying method whereby soil samples from each of the three treatments were weighed on a balance scale and oven dried for 24 hours at $105{ }^{\circ} \mathrm{C}$. This was done on a weekly basis, prior to irrigation.

The dried soil samples were weighed again and the moisture content computed using equation 2 .

$$
\% \text { Moisture Content }=\underline{\mathrm{Ww}-\mathrm{Wd}} \times 100
$$

\section{$\mathrm{Wd}$}

Where;

Wd - Dry weight of sample

Ww - Wet weight of sample

Fresh and dry mass of the plants was determined some seven weeks after planting. The plants were detached from the soil and splashed off of any moveable soil materials and other inert matter. The spinach plants were then lightly wiped off with soft paper towel to get rid of free water on the surfaces of the leaves. The fresh mass was then determined by weighing the spinach. The harvested plants were then oven dried at $75^{\circ} \mathrm{C}$ for a period of 72 hours and then weighed to determine the dry mass. 
The data collected during the course of the experiment were analysed using the Statistical Package for Social Sciences [13], whereby analysis of variance (ANOVA), was done in order to determine any significant differences between the treatments. The mean separation test was also carried out using the Least Significant Difference (LSD).

\section{RESULTS AND DISCUSSIONS}

The organic compost mulch treatment recorded the highest mean soil moisture content $(22.9 \%)$ which meant it was a better mulching material when compared to treated sewage mulch (Fig 1). The control treatment had the lowest mean moisture content $(14.4 \%)$. This was due to the fact that there was higher rate of evaporation in the no mulch treatment because the soil was exposed to evaporation agents such as solar radiation and wind currents. The differences in mean soil moisture content were significant $(\mathrm{p}<0.05)$.

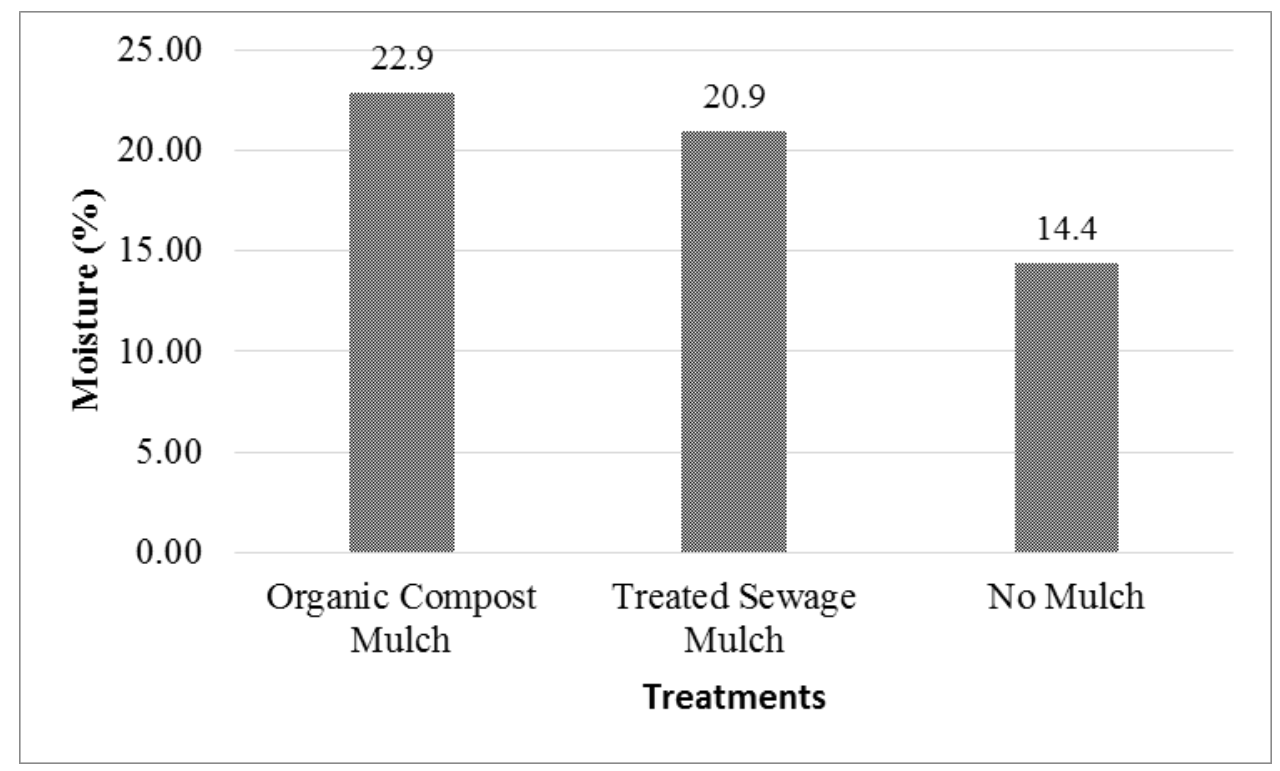

FIGURE 1: MEAN MOISTURE CONTENT BETWEEN TREATMENTS

The spinach under treated sewage mulch had the highest mean leaf width $(16.0 \mathrm{~cm})$ as compared to that grown under organic compost mulch, which had mean leaf width of $11.9 \mathrm{~cm}$. On the other hand, the control treatment had mean leaf width of $9.5 \mathrm{~cm}$ (Table 1). The differences in mean leaf width between OCM and TSM were significant, as well as those between TSM and NML $(\mathrm{p}<0.05)$. The maximum leaf length was obtained in the spinach grown under TSM with mean leaf length of $20.4 \mathrm{~cm}$. It was followed by that grown under OCM at mean leaf length of $14.6 \mathrm{~cm}$. The plants grown under NML had the least mean leaf length at $12.0 \mathrm{~cm}$ (Table 1). The analysis showed that the differences in mean leaf length were significant $(\mathrm{p}<0.05)$.

TABLE 1

MEAN VALUES FOR PARAMETERS UNDER DIFFERENT TREATMENTS

\begin{tabular}{|c|c|c|c|c|c|c|c|}
\hline \multirow{2}{*}{ Treatment } & \multicolumn{7}{|c|}{ Parameters* } \\
\cline { 2 - 8 } & $\begin{array}{c}\text { Leaf width } \\
(\mathbf{c m})\end{array}$ & $\begin{array}{c}\text { Leaf } \\
\text { length } \\
(\mathbf{c m})\end{array}$ & $\begin{array}{c}\text { Leaf area } \\
\left(\mathbf{c m}^{2}\right)\end{array}$ & $\begin{array}{c}\text { Leaf } \\
\text { number }\end{array}$ & $\begin{array}{c}\text { Plant } \\
\text { height } \\
(\mathbf{c m})\end{array}$ & $\begin{array}{c}\text { Wet mass } \\
(\mathbf{g})\end{array}$ & $\begin{array}{c}\text { Dry mass } \\
(\mathbf{g})\end{array}$ \\
\hline $\begin{array}{c}\text { Organic compost } \\
\text { mulch }\end{array}$ & $11.9^{\mathrm{a}}$ & $14.6^{\mathrm{a}}$ & $138.3^{\mathrm{a}}$ & $6^{\mathrm{a}}$ & $17.5^{\mathrm{a}}$ & $344.0^{\mathrm{a}}$ & $23.4^{\mathrm{a}}$ \\
\hline $\begin{array}{c}\text { Treated sewage } \\
\text { mulch }\end{array}$ & $16.0^{\mathrm{ab}}$ & $20.4^{\mathrm{ab}}$ & $250.5^{\mathrm{ab}}$ & $8^{\mathrm{ab}}$ & $23.7^{\mathrm{ab}}$ & $651.5^{\mathrm{ab}}$ & $43.0^{\mathrm{ab}}$ \\
\hline $\begin{array}{c}\text { No mulch } \\
\text { (control) }\end{array}$ & $9.5^{\mathrm{b}}$ & $12.0^{\mathrm{b}}$ & $55.4^{\mathrm{b}}$ & $5^{\mathrm{b}}$ & $13.7^{\mathrm{b}}$ & $317.8^{\mathrm{b}}$ & $20.9^{\mathrm{b}}$ \\
\hline
\end{tabular}

*Parameters on same column with same symbol indicate that their means were significant different. 
The results showed the highest leaf area in the spinach plants grown under treated sewage mulch, as they had an average leaf area of $250.5 \mathrm{~cm}^{2}$. It was followed by the spinach plants grown in the organic compost mulch with area of $138.3 \mathrm{~cm}^{2}$. The lowest mean leaf area was recorded from the spinach planted with no mulch at $55.4 \mathrm{~cm}^{2}$ (Table 1). The mean leaf area values were significant between OCM and TSM, as well as between TSM and NML ( $<<0.05)$. Spinach plants grown under TSM had the highest mean plant height at $23.7 \mathrm{~cm}$. It was followed by plants from OCM at $17.5 \mathrm{~cm}$, and the lowest was plants from NML at $13.7 \mathrm{~cm}$.

Both dry mass and wet mass was higher for plants grown under TSM at $651 \mathrm{~g}$ and $43.0 \mathrm{~g}$ respectively. This was followed by plants grown under OCM, with wet mass and dry mass at $344.0 \mathrm{~g}$ and $23.4 \mathrm{~g}$ respectively. The wet mass and dry mass was the lowest for plants grown under no mulch at $317 \mathrm{~g}$ and $20.9 \mathrm{~g}$ respectively (Table 1). The means for wet mass and dry mass were significant different for OCM and TSM, as well as for TSM and NML $(\mathrm{p}<0.05)$.

\section{CONCLUSION}

The results showed that the growth rate and yield of spinach plants grown on the treated sewage mulch and the organic compost mulch were better when compared to that of spinach plants grown without mulch. Treated sewage mulch produced spinach plants with the highest growth rate as the plants exhibited a higher mean leaf area, leaf width, leaf length leaf number and plant height. The dry yield across the treatments was $43.0 \mathrm{~g}$ in the treated sewage mulch, $23.4 \mathrm{~g}$ in the organic compost mulch and $20.9 \mathrm{~g}$ in the no mulch treatment. The treated sewage waste resulted in higher yield of spinach compared to all the other treatments. It is concluded that the mulch had a positive effect on the yield of spinach.

\section{REFERENCES}

[1] C. Blazey, The Australian Vegetable Garden: What's New is Old. NSW: New Holland Publishers, Sydney, 1999.

[2] N.G. Malinga, M.B. Masuku, M.B. and M.O. Raufu, M.O. (2015). Comparative Analysis Of Technical Efficiencies Of Smallholder Vegetable Farmers With And Without Credit Access In Swaziland And The Case Of The Hhohho Region. International Journal of Sustainable Agriculture Research. 2(4), 133 - 145, 2015.

[3] M.B. Masuku, and B.G. Xaba, Factors Affecting the Productivity and Profitability of Vegetables Production in Swaziland. Journal of Agricultural Studies. 1(2), 37 - 52, 2013.

[4] B.M. Msibi, W.O. Mukabwe, A.M. Manyatsi, N, Mhazo and M.T. Mararirambi, Effects of Liquid Manure on Growth and Yield of Spinach (Beta vulgaris Var cirla). In a Sub-Tropical Environment in Swaziland. Asian Journal of Agricultural Sciences. 6 (2), 40 47, 2014.

[5] H.M. Ibrahim and O.S. Fadni, O.S. Effect of Organic Fertilisers Application on Growth, Yield and Quality of Tomatoes in North Kordofan (Sandy Soil) Western Sudan. Greener Journal of Agricultural Sciences. 3(4), 299 - 304, 2012.

[6] R. Ahmad, A. Khalid, M, Arshad, Z.A. Zahir, and M. Naveed, The Effect of Raw (Un-Composted) and Composted Organic Waste Materials on Growth and Yield of Maize (Zea mays L.). Soil and Environment. 25 (2): 135 - 142, 2006.

[7] A. Bot, The Importance of Organic Matter - Key to Draught Resistant Soil and Sustained Food Production. Rome, Italy, 2005.

[8] P.J. Valarini, G. Curaqueo, A. Sequel, K. Manzano, R.Rubio, P. Carnejo, and F. Borie, Effect of Compost Application on Some Properties of a Volcanic Soil from Central South Chile. Chilean Journal of Agriculture Research. 69(3), 416 - 425, 2009.

[9] R.P. Singh, and M. Agrawal, Effect of Different Sewage Sludge Application on Growth and Yield of (Vigna radiate L.) Field Crop: Metal Uptake by Plant. Ecological Engineering. 36(7), 969 - 972, 2010.

[10] T.A. Tiruneh, A.O. Fadiran and J.S. Mtshali, Evaluation of The Risk of Heavy Metals in Sewage Sludge Intended for Agricultural Application in Swaziland. International Journal of Environmental Sciences. 5(1), 2004.

[11] M.A. Bozkurk and T. Yarilgac, the Effects of Sewage Sludge Application on the Yield, Growth, Nutrition and Heavy Metal Accumulation in Apple Trees Growing in Dry Conditions. Turkish Journal of Agriculture and Forestry. 27, 285 - $292,2003$.

[12] K.H. Ahmed, A.H. Fawy and E.S. Abdel, Study of Sewage Sludge Use in Agriculture and Its Effect on Plant and Soil. Agriculture and Biology Journal of North America. 5 (1): 1044 - 1049, 2010.

[13] IBM, IBM SPSS Software. IBM Corporation, New York, USA, 2017. 